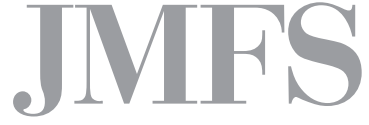

Journal of Management and Financial Sciences
Volume XIII

Issue 35 (December 2018)

pp. 61-80

Warsaw School of Economics

Collegium of Management and Finance

Elżbieta Wrońska-Bukalska

Faculty of Economics

Maria Curie-Skłodowska University in Lublin

\title{
Power of an overconfident CEO and dividend payment
}

\begin{abstract}
The aim of the paper is to identify the relation between managerial overconfidence, managerial power and dividend decisions. We have implemented the survey to detect managerial overconfidence. We collected 145 answers with financial data covering 2010-2015. We employed the managerial share in ownership as a proxy for managerial power.

We found that managerial power enhances to reveal the overconfidence in dividend decisions. We also found the pattern of behaviour of an overconfident manager having more power: more frequent dividends are paid out, but if dividend is paid out, the level and ratio of the dividend is lower.
\end{abstract}

Keywords: overconfidence, managerial power, dividend payment JEL Classification Codes: G34, G35, G41 


\section{Introduction}

Overconfidence is one of the biases and fallacies that affects a decision-making process. But overconfidence is one that is most pervasive. The concept of overconfidence comes from cognitive psychology. Overconfidence seems to be present in many real-life situations. Research in cognitive psychology establishes that people are usually overconfident. "No problem in judgment and decision making is more prevalent and more potentially catastrophic than overconfidence" [Plous, 1993, p. 217]. "Perhaps the most robust finding in the psychology of judgment is that people are overconfident" [DeBondt and Thaler, 1995, p. 389]. "Overconfidence is the mother of all biases because it gives other decision-making biases teeth" [Moore et al., 2014, p. 10].

Overconfidence can have some serious consequences. Researchers have offered overconfidence as an explanation for medical misdiagnosis, mistaken court judgement based on overconfident witnesses' statements, road accidents, politicians' decisions [Johnson, 2004]. Overconfidence has also been confirmed among epidemiologists, public health experts, ecologists, and biologists [Speirs-Bridge et al., 2010], medicine [Christensen-Szalanski and Bushyhead, 1981; Baumann et al. 1991], judiciary [Kassin et al., 1991], construction [Kidd, 1970; Szyszka, 2013, p. 41].

It is also common for managers to behave in an overconfident way. There are quite abundant amounts of research reflecting the relation between overconfidence and financial decisions [Malmendier and Tate, 2005; Ben-David et al. 2007, among others]. The financial outcome of overconfident managers' conduct is the subject of investors' assessment and investment decisions (buying, selling, market prices of shares).

The aim of our paper is to identify the pattern of dividend decisions with reference to managerial overconfidence and managerial power. We add to the discussion on the relation between overconfidence and financial decisions. The originality of our study lies in the attitude to identifying managerial overconfidence. We implemented the survey to detect the managers' beliefs. We also include the managerial power in our research. The managerial power is the factor affecting the possibility of revealing the impact of overconfidence on financial decisions (esp. dividend payment).

\section{Overconfidence: literature overview}

There is no one definition of overconfidence. Overconfidence was first studied by Adams and Adams [1961], and Oskamp [1962, 1965]. The first study on overconfidence referred to the confidence judgement and it was identified as accuracy of answers and belief in their accuracy (confidence). The research led to the results suggesting that accuracy and confidence did not match. Later, Fischhoff et al. [1977] carried out research on accuracy and confidence. 
Eventually, overconfidence was identified as a complex phenomenon. Moore and Healy [2008] identified three dimensions of overconfidence: (1) overestimation of one's actual performance relative to objective standard, (2) overplacement of one's performance relative to others, and (3) overoptimism in one's beliefs.

Overestimation is diagnosed if people's expectations of their own performance exceed their actual performance [Lichtenstein et al, 1982; Moore and Healy, 2008]. Overestimation is the belief that you are better than you really are compared to an objective standard. To measure overestimation, subjects are suggested to answer a series of questions and state their confidence for each question that their answer was correct. For example, Fischhoff et al [1977] asked their participants general-knowledge questions such as: "is absinthe (a) a liqueur or (b) a precious stone". Participants were then asked to estimate the probability (from 50 to 100\%) that they had answered the question correctly. When asking the question, an alternative can be given to an answer, or multiple answer choices, or the judgement task requires a subject to generate their own answer. But each time a subject is to evaluate their confidence that the answer is true [Gigerenzer et al, 1991, p. 506]. Overestimation is expressed through bias score (miscalibration). The bias score is calculated as the difference between the average confidence level across all questions and the proportion of correct answers.

Overplacement often occurs when people try to evaluate their competence in a certain domain relative to others. Typically, most people rate themselves above average, which is why this effect is also called better-than-average effect [Alicke and Govorun, 2005]. The simplest way to identify overplacement is to ask people to judge whether they believe themselves to be above average (or median) in a certain domain, as for example in the famous account on driving ability by Svenson [1981]. More advanced designs ask participants to specify the percentile of a distribution they believe themselves to belong to [e.g. Dunning et al, 1989; Merkle and Weber, 2011; Larrick et al, 2007]. In one survey people were instructed to use a Likert scale to rate each attribute according to how well it 'describes you', another part of this survey instructed them to indicate how well each attribute describes 'most other people' [Brown, 2012]. Benoît and Dubra [2011] propose using a stronger requirement to test overplacement. Based on their proof that maximally $2 \mathrm{x} \%$ can rate themselves rationally among the top $\mathrm{x} \%$ of the population, they suggest using this hurdle for future experiments.

Overoptimism is having more confidence in people's beliefs and abilities than is justified. The confidence in own belief has also an impact on perceiving the future. Being overoptimistic means that people overestimate their future success and underestimate the probability of failure [Alpert and Raiffa, 1982; Russo and Schoemaker, 1992]. Being overoptimistic people overestimate their future success and underestimate the probability of failure. That is why asking people to point out the expected future value and set confidence intervals, usually $90 \%$ confidence intervals contain the correct answer less than $50 \%$ of the time. People choose overly narrow confidence intervals when asked for a range that is supposed to contain a true value with a certain probability and the hit rate is low [Alpert and Raiffa, 1982; Russo and Schoemaker, 1992]. 
There are quite big amounts of research that proved that overconfidence is an important factor affecting many occupations, but overconfidence also affects financial decisions and financial performance. Overconfident managers are convinced that they have better knowledge and abilities which refrain them from getting new information, refrain them from listening to advice or an expert's opinion. If overconfident managers get new information, they use it to confirm their own beliefs [Paredes, 2004]. Reluctance to gain new knowledge makes overconfident managers miss an investment opportunity or miss the signs of failure [Goel and Thakor, 2008]. That is why overconfident managers continue a given project whatever its prospects are [Baker et al., 2007]. Overconfident managers find it difficult to learn from past experience and correct their behaviour [Heaton, 2002]. They attribute the success to themselves and at the same time they attribute the failure to others. Overconfident managers are convinced that their future will be better than other people's; they overestimate the possibility of success and at the same time they underestimate the possibility of failure [Malmendier and Tate, 2005]. This might explain the overconfident managers' attitude toward risk - they just underestimate the risk and are able to engage in a more risky project (not because it is a riskier project, but because the overconfident manager just cannot see the risk of the project).

Overconfident decision making has been observed in financial decisions. Managerial overconfidence leads to:

- Higher probability of failure for newly-established companies [Russo and Schoemaker 1992; Cooper et al. 1988];

- Overinvestment - even in negative NPV projects [Gervais et al. 2003; Malmendier and Tate, 2005];

- Excessive use of debt [Ben-David et al., 2007].

Overconfident managers are convinced that they are able to invest money better (because they are convinced that they have better knowledge and they are better than others, and that they will be more successful in the future). Therefore, they are not ready to get rid of cash and distribute net profit to shareholders as dividend. And the research results are clear: the overconfident managers are less willing to pay dividends and if they pay the dividends, they are lower. The proofs of such a behaviour were provided by: Deshmukh et al. [2013], Al-Ghazali [2014], Ben-David et al. [2007], Brav et al. [2005], Cordeiro [2009], Chen et al. [2011].

\section{Managerial power}

There are some attributes that help determine the level of CEO power. There are also quite a big number of studies proving that $\mathrm{tCEO}$ power can have significant consequences for firms [Adams et al., 2005]. For example, Fahlenbrach [2009], Villalonga and Amit [2006] or Adams et al. [2005] found that founder-managed firms have higher firm values, whilst Yermack [1996] found that such firms have lower values. In contrast, a recent study by Dowell et al. [2011] argued that CEO power is beneficial for firms facing a crisis. When quick reaction is needed, 
CEO power can again have a positive impact on performance [Finkelstein and D'Aveni, 1994; Boyd, 1995; Harris and Helfat, 1998; Coles et al. 2008].

There are some measures developed that identify the CEO power [Nanda, et al., 2013]:

- CEO Pay Slice (CPS) - Bebchuk et al. [2011] - the CEO's total compensation as a fraction of the total compensation for the firm's top five executives - the higher pay slice, the higher CEO power;

- Duality - Adams et al. [2005]; Pathan [2009], Morse et al. [2011] - one person as the CEO and as the Chair of a company's Board of Directors - if the CEO is at the same time the chair of the Board, the higher CEO power;

- Dependent Directors - Morse et al. [2011] - the number of directors appointed by the $\mathrm{CEO}$ - the more dependent directors on the board, the more likely the CEO is to exert influence over the Board;

- Tenure - Linck et al. [2008] - the number of years as the CEO in the company - the longer tenure, the higher CEO's influence over the Board;

- Ownership - Finkelstein [1992], Fischer and Pollock [2004] - the CEO stock ownership in the company - the greater CEO stock ownership, the higher CEO power;

- Founder - Adams et al. [2005], Morse et al. [2011] - the CEO is the founder of the company - if the CEO is the founder, he/she is more likely to be more powerful.

Empirical studies, such as Rozeff [1982], Jensen et al. [1992], Eckbo and Verma [1994] found that a relationship between managerial ownership and dividend payout is negative. It means that firms with higher managerial ownership tend to increase internal funds at the expense of low dividend payouts in order to finance investments. Chen et al. [2011] found that when the CEO serves as the chairman of the Board (duality), the CEO has more discretion in his/her hand in order to enhance his/her image and long-term return. Distributing dividends can potentially harm the company's long-term outlook. Executives holding both positions, therefore, are less likely to pay dividends.

However, several authors have argued that the dividend - ownership relation may not be strictly negative; it may actually turn positive due to entrenchment [Florackis et al., 2015]. In low managerial ownership companies and dispersed ownership, managers might be interested in gaining personal benefits. In low managerial ownership companies, managers are reluctant to pay dividend. In higher managerial ownership companies, managers hold a substantial portion of equity, enough to obtain voting power and to ensure that their position is secure and thus they become insulated from external disciplining forces [Demsetz, 1983; Fama and Jensen, 1983]. Managers with a significant ownership share are more likely to be more powerful, which significantly increases their propensity to pay dividends [see Hu and Kumar 2004; Jo and Pan, 2009]. Empirical evidence of this hypothesis has also been reported by Schooley and Barney [1994] for US firms, Farinha [2003] for UK firms, and Vo and Nguyen [2014] for Vietnamese firms. 


\section{Overconfidence and power of the CEO}

Overconfidence and power go hand in hand quite often. Overconfident managers are able to be promoted more easily. It makes them have more managerial power. They can negotiate higher compensations, can be the CEO and the Chair of the Board at the same time, they can hire directors [Nanda et al., 2013; Paredes, 2004]. The more powerful managers are, the more prone they are to reveal overconfidence not only in beliefs but also in behaviour and decision-making processes.

Research proved that there is a relation between managerial power and overconfidence. Managerial overconfidence is related with high dependence of the board of managers, combining the position of the CEO and the Chair, being a founder, having more than $50 \%$ share in the company, longer tenure, lower share of institutional investors [Baccar et al., 2013; Vitanova, 2014]. It is not proved what is the reason and what is the result, but one might suspect that the power positions (e.g. of the CEO) attract overconfident managers and managerial power increases managerial overconfidence and overconfident managers might increase their power, etc. Our proposition is that if managers are overconfident, their strong position will reveal their overconfidence in their decision. The managerial power can be considered as a moderator that leads to revealing and enhancing overconfidence in action, while lower power of the CEO reduces the probability of emergence of the CEO's overconfidence.

There is also research referring to the relations between overconfidence, power and financial decisions proving that [Barros and Silveira, 2008; Malmendier and Tate, 2005]:

- the more share in the capital the overconfident manager has, the investments depend fairly on cash flow (higher investment - cash flow sensitivity);

- the longer an overconfident manager is the CEO, the investments depend fairly on cash flow;

- if an overconfident CEO is the chair, the leverage is lower;

- if an overconfident CEO is a founder, the leverage is higher;

- if an overconfident CEO has more than $50 \%$ share in the capital, the leverage is higher.

While the results are not consistent, they prove that there is a statistically significant relation between overconfidence, power and financial decisions.

In the light of the above consideration on managerial overconfidence, managerial power and financial decisions, it seems justified to try to find out what is the relation between managerial overconfidence, power and dividend payout decisions. There are few studies covering the relation between overconfidence and power of the CEO and dividend decisions. Al-Ghazali [2014] and Baccar et al. [2013] noticed strong relations between power and overconfidence and dividend payment:

- the bigger ownership concentration, the higher dividends an overconfident manager pays out;

- the higher share of institutional investors in the capital, the higher dividends an overconfident manager pays out. 
Bigger ownership concentration and higher share of institutional investors means a less powerful manager. Less powerful overconfident managers are less likely to behave according their beliefs. Strong owners are able to suppress even overconfident managers and make them behave in line with the owners' expectations (to distribute cash to mitigate agency costs and overinvestment).

In sum, we can predict that lower power of the CEO will be able to control the psychological biases of the CEO and its effects on corporate decisions on dividends payment. We have developed two hypotheses:

H1: The bigger power of an overconfident CEO, the less often dividends are paid out.

$\mathrm{H} 2$ : If dividends are paid out, the bigger power of an overconfident $\mathrm{CEO}$ is connected with a lower dividend ratio.

\section{Methodology}

\subsection{Overconfidence}

It is quite challenging to identify overconfidence. This becomes an especially evident problem when it comes to managers because managers' overconfidence has been identified in the literature by using specific measures based on their behaviour or on the perception of others. Usually, in cognitive psychology, overconfidence is identified when surveying people. Surveying allows identifying people's beliefs and tracks the rationale for a specific behaviour. But when referring to managers, other ways of identifying overconfidence were developed. By far the most influential proxies for managerial overconfidence have been constructed by Malmendier and Tate [2005], whose proxies and dataset have been used in many other studies into overconfidence: based on options (longholder, holder 67), shares (net buyer), and based on press articles. Another method of identifying CEO overconfidence was first proposed by Lin et al. [2005]. They argued that overconfident managers were apt to make upward-biased earnings forecasts. If there are more upward-biases than those downward-biases, the managers are regarded as overconfident. The method based on frequency of M\&A made by managers was proposed first by Doukas and Petmezas [2007]. They argued that the more confident a manager is, the higher frequency of M\&A. They regarded a manager as overconfident if s/he made at least five M\&A during the study period. The method based on CEOs' relative compensations was proposed first by Hayward and Hambrick [1997]. They argued that the higher the CEO's relative compensation to other managers is, the more important the CEO's position, and consequently, they would be apt to be overconfident. They used 'the CEO's cash compensation divided by the second-highest-paid officer' in their measurement.

The first problem with implementing the methods described above is that these methods allow evaluating overconfidence by behavior, not by beliefs. And human behaviour might sometimes result from the strategy implemented by the company not from its managers' 
beliefs (e.g. frequency of M\&A). Additionally, those measures might be applied to specific companies that pay with stock options, that release forecasts, or the information about the CEO's compensation - these are usually listed companies. Those measures cannot be implemented to identify overconfidence among private companies.

For the sake of our research on overconfidence, we decided on surveying managers by asking questions on their beliefs, attitude and perception. We employed the Wrońska-Bukalska [2016] approach who developed a survey to detect overestimation, overplacement and overoptimism. Depending on the survey results, we decided to create two subsamples: overconfident managers and non-overconfident managers.

\subsection{Managerial power}

Managerial scope of duties and responsibilities (and power) depends on the corporate governance model (the Anglo-US model, the Japanese model, or the German model) but it also depends on corporate governance specific characteristics (dispersed or concentrated ownership, the $\mathrm{CEO}$ as the chair of the board or not, dependent or independent directors etc.). The Polish corporate governance model is closest to the German one. Corporate shareholders are the key players. Shareholders possess the authority to alter the size or composition of the supervisory board. They have also a right to take the most important corporate decisions (including dividend payment, appointing members of boards, approving of financial statements and the board members' way of conduct). Apart from shareholders, the Polish model includes two boards with separate members: the management board (composed entirely of the executives of a corporation) and the supervisory board (composed of shareholder representatives). The two boards are completely distinct; no-one may serve simultaneously on the corporation's management board and supervisory board. The supervisory board appoints and dismisses the management board, approves or presents their opinion on major management decisions; and controls and advises the management board. The supervisory board contains no "insiders", it is composed of shareholder representatives. The management board is responsible for daily management of the company. The management board is composed solely of 'insiders' (executives with the president/CEO). Due to the nature of corporate governance in Poland, there are some specific features affecting our research:

- Not every measure of CEO power might be applied, we have to exclude Duality and Dependent Directors proxy, in the Polish corporate governance model it is possible to apply only the CEO Pay Slice, Tenure, Ownership and Founder proxy as a measure of CEO power;

- The decision on dividend payment is taken by shareholders; the management board may only suggest dividend payment, while the supervisory board gives their opinion on the management's suggestion.

Eventually, we decided on managerial ownership as a variable for management power. We decided to create two subsamples: managers with a minority share in capital and managers with a majority share in capital. 


\subsection{Dividend decisions}

In our study dividend variables are dependent ones. We employed some variables:

- reflecting the frequency of dividend payment as binominal (1 paid, 0 not paid);

- reflecting the value of dividends (in thousands PLN);

- reflecting the dividend ratio (the part of net profit paid out as dividend).

For more thorough analysis (regression analysis) we employed some factors affecting dividend decisions:

- debt - Jensen [1986] assumed that debt and dividend are substitute for mitigating managers with the negative relation between debt and dividend (the lower debt, the higher dividend); we calculated debt as the relation of total liabilities in relation to total assets;

- free cash flow - Jensen [1986] in free cash flow hypotheses assumed that the higher cash flows, the more managers' discretion in spending money on investment project, even with negative NPV, that is why dividends are used to mitigate managers; we expect to find a positive relation (the higher cash flows, the higher dividend), we calculated cash flow as the relation of operating cash flow to total assets;

- investment - Myers and Majluf [1984] in the pecking order theory assumed that the more investment, the more internal sources are used; we expect to find a negative relation (the bigger investment, the lower dividend payment), we calculated investment as an increase in total assets in relation to total assets;

- net profit - Myers and Majluf [1984] in the pecking order theory assumed that the higher net profit with a constant investment programme, the higher dividend the company may pay; we expect to find a positive relation (the higher net profit, the higher dividend), we calculated net profit as the relation of net profit to total assets;

- previous year dividend payment - Lintner [1956], Lintner [1962] assumed that if the company paid dividend a year earlier, the dividend should be paid out and the company should not stop paying dividend; we expect to find a positive relation (if the dividend was paid out a year earlier, the dividend will be paid out), we calculated the payment as binominal (1 paid, 0 not paid).

\subsection{Data}

The period of the research covers the years of 2010-2015. This 6-year period is sufficient to reveal the financial result of overconfident manager decisions. Initially, we received the database of 5,000 companies. At the very beginning we chose the sample frame with the companies that were established before 2010 and ran business for the whole 2010-2015 period, have had the same president for the whole period of 2010-2015, companies with complete financial statements available, excluding insurance and banking companies. There were 438 companies left in the database. We decided on the non-probabilistic sampling method (convenience sampling). The method applied and the size of the sample was eventually determined 
by the limited budget, a short time to collect the data, willingness (or unwillingness) of CEOs to take part in surveying. We implemented the PAPI, CAPI and CATI techniques of collecting data. Eventually we collected 145 data sets with a 33\% feedback ratio. The total number of observations (company-year) is 725 .

Depending on the overconfidence survey results we decided to create two subsamples: overconfident managers (78 companies with 390 observations) and managers not overconfident (67 companies with 335 observations). Depending on the CEO power measure, we decided to create two subsamples: managers with a minority share in capital (59 companies with 295 observations) and managers with a majority share in capital (86 companies with 430 observations).

\section{Findings}

Table 1 presents some basic statistics describing the sample. The sample contains 145 companies from manufacturing (34\%), constructions (9\%), trade (38\%) and service (19\%) industries. The Shapiro-Wilk test reveals non-normal distribution of the data. The applied non-parametric test of Kruskal-Wallis for k-groups to detect whether overconfident managers are dominant in some industries. We received the test value of -2.409 and p-value of 0.492 . That means that there is no statistical difference in the overconfident managers distribution among the industries.

The average company employs 25 people, is 16 years old, is managed by one person (manager, CEO), and there are only three shareholders (owners). The manager is 55 years old, has worked for 11 years as the president and possesses app. 50\% stake in the company. More in-depth analysis did not reveal any differences in basic statistics of the company depending on managerial overconfidence. It means that the characteristics of a company managed by an overconfident and non-overconfident manager is similar and there are no statistically significant differences.

Table 1. Basic statistics describing the sample

\begin{tabular}{|l|c|c|c|c|c|}
\hline \multicolumn{1}{|c|}{ variable } & mean & median & Coefficient of variation (CV) & Chi square statistics & $p$-value \\
\hline Employees & 225 & 25 & 3.9 & 6.163 & 0.187 \\
\hline Company age & 18 & 16 & 0.5 & -1.089 & 0.276 \\
\hline The size of the management board & 1.7 & 1.0 & 0.5 & -1.048 & 0.295 \\
\hline The share of the 1' biggest shareholder & $64 \%$ & $60 \%$ & 0.4 & -0.348 & 0.728 \\
\hline The share of the 3 biggest shareholders & $91 \%$ & $100 \%$ & 0.2 & -0.277 & 0.782 \\
\hline The manager's age & 54 & 55 & 0.2 & -0.889 & 0.374 \\
\hline Managerial ownership & $50 \%$ & $50 \%$ & 0.8 & -0.352 & 0.725 \\
\hline Years as the president & 12 & 11 & 0.5 & -1.346 & 0.178 \\
\hline
\end{tabular}

Significant at ${ }^{\star} \mathrm{p}<0.10,{ }^{* *} \mathrm{p}<0.05,{ }^{* *} \mathrm{p}<0.01$

Source: Own calculations. 
The in-depth analysis covers the presence of institutional investors (financial investors, holding companies, the state) among the three biggest investors. There are 49 institutional investors among the three biggest shareholders present in 36 companies. But most of the companies with institutional investors are managed by overconfident managers. We test whether there is any statistical relation between institutional investors' presence and the manager's overconfidence We applied the statistical test. We received the value of test: -3.075 , and the p-value of 0.002 , which proves that there is a statistically significant relation between institutional investors' presence and the manager's overconfidence. If institutional investors are present among three biggest shareholders, it is more likely that the CEO is overconfident.

Another aspect of the thorough analysis is the sex of the managers. There are only 10 (7\%) women and 135 (93\%) men among the surveyed companies. After testing statistical significance, we received the value of the statistical test -0.407 and the p-value of 0.684 . There is no statistically significant relation between overconfidence and the manager's sex.

The further step of the analysis was to identify the education background of the surveyed managers. There were 86 (60\%) managers that graduated from technical studies and $31(21 \%)$ ones that graduated from economic studies. The rest of the managers $(28$, which stands for 19\%) graduated from humanities, political sciences, biology, chemistry, etc. Among the overconfident managers there are more of those with a technical degree. We tested whether there is any statistical difference in the education of overconfident managers. We applied the statistical test. We received the value of the test: -2.792 and the p-value of 0.005 , which proves that there is a statistically significant relation between education and the manager's overconfidence. If a given manager is overconfident, it is more likely that he or she graduated from technical studies.

Table 2. Basic statistics describing the companies' financial situation

\begin{tabular}{|l|c|c|c|c|c|}
\hline \multicolumn{1}{|c|}{ variable } & mean & median & $\begin{array}{c}\text { Coefficient of } \\
\text { variation (CV) }\end{array}$ & $\begin{array}{c}\text { Chi square } \\
\text { statistics }\end{array}$ & p-value \\
\hline ROS & -10.38 & 1.36 & 16.0 & -0.965 & 0.339 \\
\hline ROA & 0.23 & 4.57 & 191.0 & -2.916 & $0.004^{\star * *}$ \\
\hline ROE & -13.41 & 5.45 & 12.0 & -2.302 & $0.021^{\star *}$ \\
\hline Current liquidity ratio & 4.66 & 1.78 & 5.7 & -1.344 & 0.179 \\
\hline Quick liquidity ratio & 3.78 & 1.12 & 6.9 & -1.349 & 0.177 \\
\hline Equity to total assets & 27.72 & 50.83 & 3.9 & -0.648 & 0.517 \\
\hline Long term debt to total assets & 9.49 & 0.16 & 2.4 & -0.195 & 0.846 \\
\hline Financial debt to total assets & 18.18 & 8.33 & 1.5 & -3.679 & $0.000^{\star * *}$ \\
\hline $\begin{array}{l}\text { Investment (increase in total } \\
\text { assets to total assets) }\end{array}$ & 14.4 & 3.0 & 5.4 & -2.740 & $0.006^{\star * *}$ \\
\hline $\begin{array}{l}\text { Growth (increase in sales } \\
\text { revenue to sales revenue) }\end{array}$ & 41.2 & 1.69 & 13.0 & -1.090 & 0.276 \\
\hline
\end{tabular}

Significant at ${ }^{*} \mathrm{p}<0.10,{ }^{* *} \mathrm{p}<0.05,{ }^{* *} \mathrm{p}<0.01$

Source: Own calculations. 
Table 2 presents some basic statistics describing the financial situation of the companies from the sample. The analysed companies, depending on managerial overconfidence, differ in ROA, ROE and the level of investment and bank loans. The companies managed by an overconfident CEO have lower ROA and ROE but a higher level of investments and bank loans with statistical significance. What is interesting, the capital structure (the relation of debt to total assets and equity to total assets) does not differ. There is no statistically significant difference in financial liquidity and the pace of growth.

We prepared 6 regression models for the sample. Table 3 presents the modeling results. Model 1 and 2 assume that the dependent variable is the frequency of dividend payment. Model 3 and 4 assume that the dependent variable is the value of dividend, and model 5 and 6 assumes that the dependent variable is the dividend ratio.

Table 3. Regression models results for the sample

\begin{tabular}{|c|c|c|c|c|c|c|}
\hline & Model 1 & Model 2 & Model 3 & Model 4 & Model 5 & Model 6 \\
\hline & $\begin{array}{l}\text { The frequency of } \\
\text { dividend }\end{array}$ & $\begin{array}{c}\text { The frequency } \\
\text { of dividend }\end{array}$ & $\begin{array}{l}\text { Value of } \\
\text { dividend }\end{array}$ & $\begin{array}{l}\text { Value of } \\
\text { dividend }\end{array}$ & Dividend ratio & Dividend ratio \\
\hline $\begin{array}{l}\text { Dividend payment } \\
\text { in previous year }\end{array}$ & $\begin{array}{c}\text { Beta: } 2.508 \\
\text { p-value: } 0.000^{\star \star \star}\end{array}$ & $\begin{array}{c}2.500 \\
0.000^{\star \star \star}\end{array}$ & $\begin{array}{l}44009.191 \\
0.000^{\star \star *}\end{array}$ & $\begin{array}{c}3607.573 \\
0.040 * *\end{array}$ & $\begin{array}{c}0.274 \\
0.000^{\star \star \star}\end{array}$ & $\begin{array}{c}0.276 \\
0.000^{\star \star \star}\end{array}$ \\
\hline Free cash flow & $\begin{array}{l}0.061 \\
0.675\end{array}$ & $\begin{array}{l}0.124 \\
0.436\end{array}$ & $\begin{array}{c}953.254 \\
0.897\end{array}$ & $\begin{array}{c}368.719 \\
0.770\end{array}$ & $\begin{array}{l}0.025 \\
0.204\end{array}$ & $\begin{array}{l}0.030 \\
0.158\end{array}$ \\
\hline Debt & $\begin{array}{l}-0.476 \\
0.055^{\star}\end{array}$ & $\begin{array}{c}-0.424 \\
0.167\end{array}$ & $\begin{array}{c}-621.247 \\
0.777\end{array}$ & $\begin{array}{c}-80.498 \\
0.826\end{array}$ & $\begin{array}{c}-0.007 \\
0.239\end{array}$ & $\begin{array}{c}-0.006 \\
0.362\end{array}$ \\
\hline Net profit & $\begin{array}{c}2.163 \\
0.003^{\star * \star}\end{array}$ & $\begin{array}{c}3.199 \\
0.001^{\star \star \star}\end{array}$ & $\begin{array}{c}1549.676 \\
0.890\end{array}$ & $\begin{array}{c}483.431 \\
0.852\end{array}$ & $\begin{array}{l}0.018 \\
0.561\end{array}$ & $\begin{array}{l}0.039 \\
0.365\end{array}$ \\
\hline Investment & $\begin{array}{c}-1.960 \\
0.000^{\star * \star}\end{array}$ & $\begin{array}{c}-1.727 \\
0.000 * * \star\end{array}$ & $\begin{array}{c}-2194.843 \\
0.706\end{array}$ & $\begin{array}{c}-876.938 \\
0.379\end{array}$ & $\begin{array}{c}-0.047 \\
0.003^{\star * \star}\end{array}$ & $\begin{array}{l}-0.037 \\
0.026^{\star \star}\end{array}$ \\
\hline $\begin{array}{l}\text { Managerial } \\
\text { overconfidence }\end{array}$ & $x$ & $\begin{array}{c}0.149 \\
0.099^{\star}\end{array}$ & $x$ & $\begin{array}{l}2325.920 \\
0.001^{* \star *}\end{array}$ & $x$ & $\begin{array}{c}0.756 \\
0.003^{\star \star \star}\end{array}$ \\
\hline $\begin{array}{l}\text { Managerial } \\
\text { ownership }\end{array}$ & $x$ & $\begin{array}{l}-0.575 \\
0.096^{*}\end{array}$ & $x$ & $\begin{array}{c}-15331.864 \\
0.000 \star \star \star\end{array}$ & $x$ & $\begin{array}{l}-0.100 \\
0.021^{\star *}\end{array}$ \\
\hline $\mathrm{F}$ & $\begin{array}{c}262.082 \\
0.000^{\star \star \star}\end{array}$ & $\begin{array}{c}218.488 \\
0.000^{\star \star \star}\end{array}$ & $\begin{array}{c}4.524 \\
0.000^{\star \star \star}\end{array}$ & $\begin{array}{c}8.787 \\
0.000^{\star \star \star}\end{array}$ & $\begin{array}{c}27.375 \\
0.000^{\star \star \star}\end{array}$ & $\begin{array}{c}17.510 \\
0.000^{\star \star \star}\end{array}$ \\
\hline R square & 0.303 & 0.321 & 0.030 & 0.099 & 0.160 & 0.180 \\
\hline
\end{tabular}

Significant at ${ }^{\star} \mathrm{p}<0.10,{ }^{* *} \mathrm{p}<0.05,{ }^{* * *} \mathrm{p}<0.01$

Source: Own calculations.

Free cash flow and debt are not statistically important variables. But a positive relation between free cash flow and dividend, and a negative relation between debt and dividend was confirmed.

For every model, the proxy for the dividend paid in the previous year is important. The net profit proxy is also important for dividend decisions. There is a statistically significant positive relation between net profit and dividend, which means that the higher net profit, the more prone the company is to decide on paying out dividend. But the net profit seems not to have any relation with the dividend value and dividend ratio. 
The investment proxy is also important for dividend decisions and the dividend ratio. There is a statistically significant negative relation between investment and the dividend decision and dividend ratio, which is consistent with the theory.

But what is the most important, for every dependent variable the proxy for managerial overconfidence and managerial ownership is statistically important. While the relation between managerial overconfidence is positive, which means that the higher overconfidence, the more often dividend is paid out, the higher dividend is and the higher dividend ratio is. But the relation between managerial ownership is negative, which means that the higher managerial ownership, the less often dividend is paid out, the value of dividend is lower and the lower is the dividend ratio.

In the next step, we conducted more thorough research in subsamples. Table 4 presents the descriptive statistics of dividend decisions in subsamples. We broadened our research also to cover the net profit.

Table 4. Descriptive statistics of dividend decisions in subsamples (mean, median, coefficient of variation)

\begin{tabular}{|c|c|c|c|c|c|c|c|c|}
\hline & \multicolumn{4}{|c|}{ Minority share subsample } & \multicolumn{4}{|c|}{ Majority share subsample } \\
\hline & 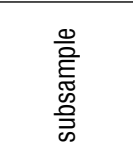 & 흔 $\frac{\text { 등 }}{\frac{0}{0}}$ & 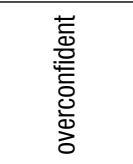 & 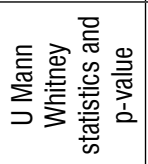 & $\begin{array}{l}\frac{0}{0} \\
\text { E్ } \\
\text { ळ. } \\
\text { क }\end{array}$ & 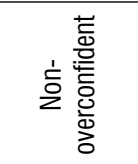 & 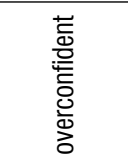 & 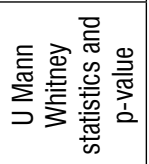 \\
\hline $\begin{array}{l}\text { Number of } \\
\text { observations }\end{array}$ & 295 & 140 & 155 & $x$ & 430 & 250 & 180 & $x$ \\
\hline $\begin{array}{l}\text { The value } \\
\text { of net profit } \\
\text { (thousand PLN) }\end{array}$ & $\begin{array}{c}91.2 \\
141 \\
383.6\end{array}$ & $\begin{array}{c}145.7 \\
298 \\
528.3\end{array}$ & $\begin{array}{c}41.9 \\
103 \\
154.7\end{array}$ & $\begin{array}{c}-2.021 \\
0.043^{\star *}\end{array}$ & $\begin{array}{l}878 \\
110 \\
4.4\end{array}$ & $\begin{array}{c}1.159 \\
162 \\
5.4\end{array}$ & $\begin{array}{c}489 \\
82 \\
2.5\end{array}$ & $\begin{array}{c}-2.163 \\
0.031^{\star *}\end{array}$ \\
\hline $\begin{array}{l}\text { Number of } \\
\text { observations with } \\
\text { net profit }\end{array}$ & 224 & $115(82 \%)$ & $109(70 \%)$ & $\begin{array}{l}-2.367 \\
0.018^{\star \star}\end{array}$ & $340(79 \%)$ & $206(82 \%)$ & $134(74 \%)$ & $\begin{array}{c}-1.998 \\
0.046^{\star *}\end{array}$ \\
\hline $\begin{array}{l}\text { The value of net } \\
\text { profit if net profit } \\
\text { (thousand PLN) }\end{array}$ & $\begin{array}{c}120.6 \\
501 \\
436.34\end{array}$ & $\begin{array}{c}177.4 \\
481 \\
578.4\end{array}$ & $\begin{array}{c}60.6 \\
515 \\
181.4\end{array}$ & $\begin{array}{c}-0.114 \\
0.909\end{array}$ & $\begin{array}{l}1.3 \\
256 \\
4.8\end{array}$ & $\begin{array}{c}1.5 \\
272 \\
5.9\end{array}$ & $\begin{array}{l}941 \\
245 \\
2.4\end{array}$ & $\begin{array}{l}-1.707 \\
0.088^{\star}\end{array}$ \\
\hline $\begin{array}{l}\text { Number of } \\
\text { observations with } \\
\text { dividend payment } \\
\text { (for the companies } \\
\text { with net profit) }\end{array}$ & $100(45 \%)$ & $54(47 \%)$ & $46(42 \%)$ & $\begin{array}{c}-0.613 \\
0.258\end{array}$ & $156(46 \%)$ & $84(41 \%)$ & $72(54 \%)$ & $\begin{array}{c}-2.339 \\
0.019 * *\end{array}$ \\
\hline $\begin{array}{l}\text { The value of } \\
\text { dividend (for } \\
\text { companies that } \\
\text { paid out dividend) }\end{array}$ & $\begin{array}{c}118.8 \\
1.1 \\
312.2\end{array}$ & $\begin{array}{c}136.7 \\
790 \\
369.4\end{array}$ & $\begin{array}{c}97.7 \\
1.7 \\
229.9\end{array}$ & $\begin{array}{c}-0.920 \\
0.358\end{array}$ & $\begin{array}{l}738 \\
146 \\
2.4\end{array}$ & $\begin{array}{l}1.0 \\
182 \\
3.1\end{array}$ & $\begin{array}{l}384 \\
100 \\
914\end{array}$ & $\begin{array}{l}-1.664 \\
0.096^{\star}\end{array}$ \\
\hline $\begin{array}{l}\text { Dividend ratio (for } \\
\text { companies that } \\
\text { paid dividend out) }\end{array}$ & $\begin{array}{l}65.2 \\
69.5 \\
34.7\end{array}$ & $\begin{array}{l}62.5 \\
70.1 \\
36.8\end{array}$ & $\begin{array}{l}68.4 \\
65.9 \\
32.2\end{array}$ & $\begin{array}{c}-0.521 \\
0.603\end{array}$ & $\begin{array}{l}56.5 \\
58.1 \\
37.6\end{array}$ & $\begin{array}{l}61.5 \\
68.9 \\
37.3\end{array}$ & $\begin{array}{l}50.7 \\
43.3 \\
37.5\end{array}$ & $\begin{array}{l}-1.692 \\
0.091^{*}\end{array}$ \\
\hline
\end{tabular}

Significant at ${ }^{\star} \mathrm{p}<0.10,{ }^{* *} \mathrm{p}<0.05,{ }^{* *} \mathrm{p}<0.01$

Source: Own calculations. 
For the subsample of the minority managerial share, the average value of net profit is lower for overconfident managers, the frequency of having net profit is lower for overconfident managers. The differences in the number of observations with net profit and the value of net profit depending on overconfidence are statistically significant. But the overconfidence seems not to show the relation with the frequency of dividend payment, the dividend value and dividend ratio.

For the subsample of the majority managerial share, the average value of net profit is lower for overconfident managers, the frequency of having net profit is lower for overconfident managers, if a company records a profit, it is again lower for overconfident managers. If a company posts a profit, it is more probable that the overconfident manager will pay dividend out, but for the companies paying dividend the value of dividend is lower for overconfident managers, and the dividend ratio is lower for overconfident managers. In every decision the overconfidence is statistically significant.

We might conclude that in the companies with less managerial power (minority managerial ownership), managerial overconfidence matters only if the financial performance is concerned (net profit is less frequent and is lower) but does not matter when the dividend decisions are concerned. It seems that the owners have the decisive power over managerial overconfidence.

We might also conclude that in the companies with more managerial power (majority managerial ownership), managerial overconfidence matters in every decision. The pattern of dividend decisions is as follows: overconfident managers report net profit less often; if they have net profit, it is lower; if overconfident managers have net profit, it is more probable that dividend will be paid out; but if dividend is paid out, its value and ratio is lower. It seems that managers having power are more prone to revealing overconfidence in dividend decisions.

The next step of our analysis is to develop univariate regression analysis (OLS) to model the relationship between the dependent variables (such as the frequency of net profit, the value of net profit, the frequency to pay out dividend, the value of dividend, the dividend ratio) and overconfidence in subsamples. Table 5 and 6 present regressions model results in subsamples.

Table 5. The regression analysis for the minority share subsample

\begin{tabular}{|l|c|c|c|c|c|}
\cline { 2 - 6 } \multicolumn{1}{c|}{} & Model 1 & Model 2 & Model 3 & Model 4 & Model 5 \\
\cline { 2 - 6 } & $\begin{array}{c}\text { Frequency of net } \\
\text { profit }\end{array}$ & $\begin{array}{c}\text { The value of net } \\
\text { profit if net profit is } \\
\text { reported }\end{array}$ & $\begin{array}{c}\text { The frequency of } \\
\text { dividend if net profit } \\
\text { is reported }\end{array}$ & $\begin{array}{c}\text { The value of } \\
\text { dividend if dividend } \\
\text { paid out }\end{array}$ & $\begin{array}{c}\text { The dividend ratio if } \\
\text { dividend paid out }\end{array}$ \\
\hline Managerial & Beta: $-0.663 ;$ & $\begin{array}{c}-116811.576 \\
\text { p-value: } \mathbf{0 . 0 1 9 * *}\end{array}$ & 0.095 & 18368.890 & 0.059 \\
overconfidence & $5.703 ;$ & $4.065 ;$ & 0.374 & 0.444 & 0.397 \\
\hline F, & 0.017 & 0.045 & 0.373 & 0.590 & 0.722 \\
p-value & 0.019 & 0.018 & 0.004 & 0.006 & 0.397 \\
\hline R square & & $\mathbf{0 . 0 4 5}$ & 0.007 \\
\hline
\end{tabular}

Significant at ${ }^{*} \mathrm{p}<0.10,{ }^{* *} \mathrm{p}<0.05,{ }^{* * *} \mathrm{p}<0.01$

Source: Own calculations. 
Table 6. The regression analysis for the majority share subsample

\begin{tabular}{|c|c|c|c|c|c|}
\hline & Model 1 & Model 2 & Model 3 & Model 4 & Model 5 \\
\hline & $\begin{array}{l}\text { Frequency of net } \\
\text { profit }\end{array}$ & $\begin{array}{l}\text { The value of net } \\
\text { profit if net profit is } \\
\text { reported }\end{array}$ & $\begin{array}{l}\text { The frequency of } \\
\text { dividend if net profit } \\
\text { is reported }\end{array}$ & $\begin{array}{c}\text { The value of } \\
\text { dividend if dividend } \\
\text { paid out }\end{array}$ & $\begin{array}{l}\text { The dividend ratio if } \\
\text { dividend paid out }\end{array}$ \\
\hline $\begin{array}{l}\text { Managerial } \\
\text { overconfidence }\end{array}$ & $\begin{array}{c}\text { Beta: }-0.474 ; \\
\text { p-value: } \mathbf{0 . 0 4 6 * *}\end{array}$ & $\begin{array}{c}-193.577 \\
\mathbf{0 . 0 8 8 *}\end{array}$ & $\begin{array}{c}0.195 \\
\mathbf{0 . 0 2 8}\end{array}$ & $\begin{array}{c}-657.387 \\
\mathbf{0 . 0 8 3 *}\end{array}$ & $\begin{array}{l}-0.108 \\
0.075^{\star}\end{array}$ \\
\hline $\mathrm{F}, \mathrm{p}$-value & $3.961 ; 0.047$ & $2.835 ; 0.087$ & $4.972 ; 0.027$ & $3.049 ; 0.083$ & $3.214 ; 0.075$ \\
\hline R square & 0.014 & 0.002 & 0.014 & 0.019 & 0.020 \\
\hline
\end{tabular}

Significant at ${ }^{\star} \mathrm{p}<0.10,{ }^{* *} \mathrm{p}<0.05,{ }^{* *} \mathrm{p}<0.01$

Source: Own calculations.

The regression analysis for the subsample of minority managerial ownership (table 5) confirms that managerial overconfidence is statistically significant only when the financial performance is concerned. The relation between financial performance and managerial overconfidence is negative (the higher overconfidence, the lower financial performance).

The regression analysis for the subsample of majority managerial ownership (table 6) confirms that managerial overconfidence is statistically significant for every financial decision. We identified the relation between financial performance and managerial overconfidence (a negative relation: the higher overconfidence, the lower financial performance) but also between managerial overconfidence and the frequency of dividend payment (a positive relation: the higher overconfidence, the higher propensity to pay out dividends) and between overconfidence and the value and level of dividend if dividend is paid out (a negative relation: the higher overconfidence, the lower dividend and lower dividend ratio).

\section{Summary}

The aim of this study was to identify dividend decisions taken by overconfident and powerful managers. We found that the overconfidence of a less powerful manager (a manager having a minority share in ownership) is important only for the frequency and the value of net profit. In decisions of dividend payment, the manager's overconfidence is suppressed by the owners. We also found that overconfidence of a more powerful manager (a manager having a majority share in ownership) is important for all the decisions (the frequency and the value of net profit, the frequency and the value of dividend and the dividend ratio). It is consistent with our expectations assuming that if managers are overconfident, their strong position will reveal their overconfidence in their decisions.

We expected to find that the bigger power of an overconfident manager, the less often dividends are paid out, and if dividends are paid out, the bigger power of an overconfident manager is connected with a lower dividend ratio. The research revealed different dividend decision patterns of overconfident and more powerful managers. We found that the higher 
overconfidence of a more powerful manager, the higher propensity to pay out dividends is but if dividend is paid out, there is a lower value and ratio of dividend.

We found only a partial confirmation of previous research [Al-Ghazali, 2014; Baccar et al., 2013] and our expectations. We think that the higher propensity to pay out dividends might be explained by overestimating the probability of success by overconfident managers and their willingness to signal good business prospects with the decision to pay out dividend. However, the reluctance to get rid of cash and invest more makes overconfident managers pay out lower dividends.

\section{References}

1. Adams R., Almeida H., Ferreira, D., 2005. Powerful CEOs and their impact on corporate performance. Review of Financial Studies, Vol. 18, No. 4, pp. 1403-1432.

2. Adams J.K., Adams P.A., 1961. Realism of Confidence Judgements. Psychological Review, Vol. 68, pp. 33-45.

3. Al-Ghazali A.M., 2014. The Economic and Behavioural Factors Affecting Corporate Dividend Policy: Theory and Evidence. Retrieved from: http://opus.bath.ac.uk/46574/1/Abdullah_s_Thesis.pdf

4. Aivazian V., Booth L., Cleary S., 2003. Do Emerging Markets Firms follow Different Dividend Policies from U.S. firms? The Journal of Financial Research, Vol. 26, No. 3, pp. 71-387.

5. Alicke M.D., Govorun O., 2005. The Better-Than-Average Effect. In: M.D. Alicke, D.A. Dunning, J.I. Krueger (Eds.), The Self in Social Judgment. New York: Psychology Press.

6. Alpert M., Raiffa H., 1982. A progress report on the training of probability assessors. In: D. Kahneman, P. Slavic, L.A. Tversky (Eds.), Judgment under uncertainty: Heuristics and biases. Cambridge, England: Cambridge University Press.

7. Baccar A., Mohamed E.B., Bouri A., 2013. Managerial Optimism, Overconfidence and Board Characteristics: Toward a New Role of Corporate Governance. Australian Journal of Basic and Applied Sciences, Vol. 7, No. 7, pp. 287-301.

8. Baker M., Ruback R.S., Wurgler J., 2007. Behavioral Corporate Finance: A Survey. In: B.E. Eckbo (Ed.), Handbook of Empirical Corporate Finance. Amsterdam: Elsevier/North Holland.

9. Barros L.A.B. de C., Silveira A. de M., 2008. Overconfidence, Managerial Optimism. Brazilian Review of Finance, Vol. 6, No. 3, pp. 293-335.

10. Baumann A.O., Deber R.B., Thompson G.G., 1991. Overconfidence Among Physicians and Nurses: The 'Micro-Certainty, Macro-Uncertainty' Phenomenon. Social Science and Medicine, Vol. 32, No. 2, pp. 167-174.

11. Bebchuk L.A., Cremers K.J.M., Peyer U.C., 2011. The CEO pay slice. Journal of Financial Economics, Vol. 102, pp. 199-221.

12. Ben-David I., Graham J.R., Harvey C., 2007. Managerial Overconfidence and Corporate Policies. Retrieved from: www.nber.prg/papers/w13711

13. Benoît J. -P., Dubra J., 2011. Apparent Overconfidence. Econometrica, Vol. 79, No. 5, pp. 15911625. 
14. Boyd B.K., 1995. CEO duality and firm performance: A contingency model. Strategic Management Journal, Vol. 16, No. 4, pp. 301-312.

15. Brav A., Graham J.R., Harvey C., Michaely R., 2005. Payout Policy in the $21^{\text {st }}$ Century. Journal of Financial Economics, Vol. 77, No. 3, pp. 483-527.

16. Brown J.D., 2012. Understanding the better than average effect: Motives (still) matter. Personality and Social Psychology Bulletin, Vol. 38, No. 2, pp. 209-219.

17. Chen S., Zheng H., Wu S., 2011. Senior manager overconfidence, managerial discretion and dividend policy: A study of Chinese listed Companies. African Journal of Business Management, Vol. 5, No. 32, pp. 12641-12652.

18. Christensen-Szalanski J.J., Bushyhead J.B., 1981. Physicians' Use of Probabilistic Information in a Real Clinical Setting. Journal of Experimental Psychology: Human Perception and Performance, Vol. 7, No. 4, pp. 928-935.

19. Coles J.L., Daniel N.D., Naveen L., 2008. Boards: does one size fit all? Journal of Financial Economics, Vol. 87, No. 2, pp. 329-356.

20. Cooper A.C., Woo C.Y., Dunkelberg W.C., 1988. Entrepreneurs' Perceived Chances for Success. Journal of Business Venturing, Vol. 3, No. 2, pp. 97-108.

21. Cordeiro L., 2009. Managerial Overconfidence and Dividend Policy. Retrieved from: https:// ssrn.com/abstract $=1343805$

22. DeBondt W.F., Thaler R., 1995. Financial decision-making in markets and firms: a behavioral perspective. Retrieved from: http://www.nber.org/papers/w4777.pdf

23. Demsetz H., 1983. The Structure of Ownership and the Theory of the Firm. Journal of Law and Economics, Vol. 26, Iss. 2, pp. 375-390.

24. Deshmukh S., Goel A.M., Howe K.M., 2013. CEO Overconfidence and Dividend Policy. Journal of Financial Intermediation, Vol. 22, No. 3, pp. 440-463.

25. Doukas J.A., Petmezas D., 2007. Acquisitions, Overconfident Managers and Self-Attribution Bias. European Financial Management, Vol. 13, No. 3, pp. 531-577.

26. Dowell G.W.S., Shackell M.B., Stuart N.V., 2011. Boards, CEOs, and surviving a financial crisis: Evidence from the internet shakeout. Strategic Management Journal, Vol. 32, No. 10, pp. 1025-1045.

27. Dunning D., Meyerowitz J.A., Holzberg A.D., 1989. Ambiguity and Self-Evaluation: The Role of Idiosyncratic Trait Definitions In Self-Serving Assessments of Ability. Journal of Personality and Social Psychology, Vol. 57, pp. 1082-1090.

28. Eckbo B.E., Verma S., 1994. Managerial Shareownership, Voting Power, and Cash Dividend Policy. Journal of Corporate Finance, Vol. 1, pp. 33-62.

29. Fahlenbrach R., 2009. Founder-CEOs, investment decisions, and stock market performance. Journal of Financial and Quantitative Analysis, Vol. 44, No. 2, pp. 439-466.

30. Fama E.F., Jensen M.C., 1983. Separation of Ownership and Control. Journal of Law and Economics, Vol. 26, pp. 301-325.

31. Farinha J., 2003. Dividend Policy, Corporate Governance and the Managerial Entrenchment Hypothesis: An Empirical Analysis. Journal of Business Finance and Accounting, Vol. 30, Iss. 9-10, (2003), pp. 1173-1209. 
32. Finkelstein S., 1992. Power in Top Management Teams: Dimensions, Measurement, and Validation. Academy of Management Journal, Vol. 35, No. 3, pp. 505-538.

33. Finkelstein S., D’Aveni R.A., 1994. CEO duality as a double-edged sword: How boards of directors balance entrenchment avoidance and unity of command. Academy of Management Journal, Vol. 37, No. 5, pp. 1079-1108.

34. Fischer H.M., Pollock T.G., 2004. Effects of social capital and power on surviving transformational change: The case of initial public offerings. Academy of Management Journal, Vol. 47, No. 4, pp. 463-481.

35. Fischhoff B., Slovic P., Lichtenstein S., 1977. Knowing with Certainty: The Appropriateness of Extreme Confidence. Journal of Experimental Psychology: Human Perception and Performance, Vol. 3, pp. 552-564.

36. Florackis C., Kanas A., Kostakis A., 2015. Dividend policy, managerial ownership and debt financing. A non-parametric perspective. European Journal of Operational Research, Vol. 241, pp. 783-795.

37. Gervais S., Heaton J.B., Odean T., 2003. Overconfidence, Investment Policy, and Executive Stock Options. Retrieved from: https://ssrn.com/abstract $=361200$

38. Gigerenzer G., Hoffrage U., Kleinbolting H., 1991. A Brunswikian Theory of Confidence. Psychological Review, Vol. 98, No. 4, pp. 506-528.

39. Goel A.M., Thakor A.V., 2008. Overconfidence, CEO Selection, and Corporate Governance. The Journal of Finance, Vol. 63, Iss. 6, pp. 2737-2784.

40. Harris D., Helfat C.E., 1998. CEO duality, succession, capabilities and agency theory: Commentary and research agenda. Strategic Management Journal, Vol. 19, No. 9, pp. 901-904.

41. Hayward M.L.A., Hambrick D.C., 1997. Explaining the Premiums Paid for Large Acquisitions: Evidence of CEO Hubris. Administrative Science Quarterly, Vol. 42, No. 1, pp. 103-127.

42. Heaton J.B., 2002. Managerial Optimism and Corporate Finance. Financial Management, Vol. 31, pp. 33-45.

43. Hu A., Kumar p., 2004. Managerial Entrenchment and Payout Policy. The Journal of Financial and Quantitative Analysis, Vol. 39, No. 4, pp. 759-790.

44. Jensen M.C., 1983. Separation of Ownership and Control. Journal of Law and Economics, Vol. 26, pp. 301-325.

45. Jensen M.C., 1986. Agency Costs of Free Cash Flow, Corporate Finance, and Takeovers. The American Economic Review, Vol. 76, No. 2, pp. 323-329.

46. Jensen G.R., Solberg D.P., Zorn T.S., 1992. Simultaneous Determination of Insider Ownership, Debt, and Dividend Policies. Journal of Financial and Quantitative Analysis, Vol. 27, No. 2, pp. 247-263.

47. Jo H., Pan C., 2009. Why are firms with entrenched managers more likely to pay dividends? Review of Accounting and Finance, Vol. 8, Iss. 1, pp. 87-116.https://doi.org/10.1108/14757700910934256

48. Johnson D.D.P., 2004. Overconfidence and War. The Havoc and Glory of Positive Illusions, Cambridge, Massachusetts: Harvard University Press.

49. Kassin S.M., Rigby S., Castillo S.R., 1991. The Accuracy-Confidence Correlation in Eyewitness Testimony: Limits and Extensions of the Retrospective Self-Awareness Effect. Journal of Personality and Social Psychology, Vol. 61. No. 5, pp. 698-707. 
50. Kidd J.B., 1970. The Utilization of Subjective Probabilities in Production Planning. Acta Psychologica, Vol. 34, pp. 338-347.

51. Larrick R.P., Burson K.A., Soll J.B., 2007. Social Comparison and Confidence: When Thinking You're Better than Average Predicts Overconfidence (and When It Does Not). Organizational Behavior and Human Decision Processes, Vol. 102, pp. 76-94.

52. Lichtenstein S., Fischhoff B., Phillips L.D., 1982. Calibration of probabilities: the state of the art to 1980. In: D. Kahneman, P. Slovic, A. Tversky (Eds.), Judgment Under Uncertainty: Heuristics and Biases. Cambridge, UK: Cambridge University Press.

53. Lin Y. -H., Hu S. -Y., Chen M. -S., 2005. Managerial Optimism and Corporate Investment: Some Empirical Evidence from Taiwan. Pacific-Basin Finance Journal, Vol. 13, pp. 523-546.

54. Linck J.S., Netter J.M., Yang T., 2008. The determinants of board structure. Journal of Financial Economics, Vol. 87, Iss. 2, pp. 308-328.

55. Lintner J., 1956. Distribution of Incomes of Corporations among Dividends, Retained Earnings and Taxes. The American Economic Review, Vol. 46, pp. 97-113.

56. Lintner J., 1962. Dividends, Earnings, Leverage, Stock, Prices and the Supply of Capital to Corporations. Review of Economics and Statistics, Vol. XLIV, No. 3, pp. 243-269.

57. Malmendier U., Tate G., 2005. CEO Overconfidence and Corporate Investment. Journal of Finance, Vol. 60, No. 6, pp. 2661-2700.

58. Merkle C., Weber M., 2011. True overconfidence: The inability of rational information processing to account for apparent overconfidence. Organizational Behavior and Human Decision Processes, Vol. 116, Iss. 2, pp. 262-271.

59. Moore D., Healy P.J., 2008. The Trouble with Overconfidence. Psychological Review, Vol. 115, pp. 502-517.

60. Moore D., Tenney E.R., Haran U., 2014. Overprecision In Judgment. In: G. Wu and G. Keren (Eds.), Handbook of Judgment and Decision Making, New York: Wiley.

61. Morse A., Nanda V., Seru A., 2011. Are Incentive Contracts Rigged by Powerful CEOs? Journal of Finance, Vol. 66, No. 5, pp. 1779-1821.

62. Myers S.C., Majluf N.S., 1984. Corporate financing and investment decisions when firms have information that investors do not have. Journal of Financial Economics. Vol. 13, No. 2, pp. 187-221.

63. Nanda V.K., Silveri S., Han S., 2013. CEO Power and Decision-Making Under Pressure. Midwest Finance Association 2013 Annual Meeting Paper. Retrieved from: https://ssrn.com/ abstract=2136624 or http://dx.doi.org/10.2139/ssrn.2136624

64. Oskamp S. 1962. The Relationship of Clinical Experience and Training Methods to Several Criteria of Clinical Prediction. Psychological Monographs: General and Applied, Vol. 76, No. 28, pp. 1-27.

65. Oskamp S. 1965. Overconfidence in Case-Study Judgements. Journal of Consulting Psychology, No. 29, pp. 261-265.

66. Paredes T.A., 2004. Too Much Pay, Too Much Deference: Is CEO Overconfidence the Product of Corporate Governance? Washington U. School of Law Working Paper No. 04-08-02. Retrieved from: http://ssrn.com/abstract $=587162$ 
67. Pathan S., 2009. Strong boards, CEO power and bank risk-taking. Journal of Banking \& Finance, Vol. 33, Iss. 7, pp. 1340-1350.

68. Plous S., 1993. The Psychology of Judgment and Decision Making. New York: McGraw-Hill.

69. Rozeff M.S., 1982. Growth, Beta and Agency Costs as Determinants of Dividend Payout Ratios. Journal of Financial Research, Vol. 5, No. 3, pp. 249-259.

70. Russo J.E., Schoemaker P.J.H., 1992. Managing Overconfidence. Sloan Management Review, Vol. 33, No. 2, pp. 7-17.

71. Schooley D.K., Barney L.D., 1994. Using Dividend Policy and Managerial Ownership to Reduce Agency Costs. Journal of Financial Research, Vol. 17, Iss. 3, pp. 363-372.

72. Speirs-Bridge A., Fidler F., McBride M., Flander L., Cumming G., Burgman M., 2010. Reducing overconfidence in the interval judgments of experts. Risk Analysis, Vol. 30, pp. 512-523.

73. Svenson O., 1981. Are We All Less Risky and More Skillful Than Our Fellow Drivers? Acta Psychologica, Vol. 47, pp. 143-148.

74. Szyszka A., 2013. Behavioral Finance and Capital Markets. How Psychology Influences Investors and Corporations. New York: MacMillan.

75. Villalonga B., Amit R., 2006. How do family ownership, control and management affect firm value? Journal of Financial Economics, Vol. 80, No. 2, pp. 385-417.

76. Vitanova I., 2014. Nurturing CEO Overconfidence: The Dynamics of Corporate Governance, Managerial Beliefs and Firm Performance. Retrieved from: http://www.iae-aix.com/affi2014/ docs/phd/nurturing_ceo_overconfidence.pdf

77. Vo D.H., Nguyen V.T. -Y., 2014. Managerial Ownership, Leverage and Dividend Policies: Empirical Evidence from Vietnam's Listed Firms. International Journal of Economics and Finance, Vol. 6, No. 5, pp. 274-284.

78. Wrońska-Bukalska E., 2016. Overconfidence Students and Managers - Comparative Analysis. Proceedings of the Economics \& Finance Conferences, Published by International Institute of Social and Economic Sciences. pp. 349-361.

79. Yermack D., 1996. Higher market valuation of companies with a small board of directors. Journal of Financial Economics, Vol. 40, No. 2, pp. 185-211. 